21

\title{
The Relationship between the United States and the Native Hawaiian People A Case of Spouse Abuse Brenda Luana Machado Lee
}

Hawaii speaks out to the United States:

- I am Hawaii. Remember me? I was once a beauty. My body was that of innocence, and then I was discovered.

(My people were innocent and pure, and we had our religious beliefs. Our islands were virgin land, then Capt. Cook arrived and exposed me to the Western World.)

- I was naked, and so you came to clothe me.

(Your missionaries came to bring in a new religion.)

- I liked my beautiful new clothes.

(The religion they brought was cherished by my people.)

- You craved my love because you saw that I was beautiful, clothed as I was, and then you raped me.

(You overthrew the Monarchy of Hawaii, under Queen

Liliuokalani, in 1893.)

- I was humbled and humiliated.

(My people began to develop inferiority complexes in the presence of your haole superiority.)

- Yet you meant me no wrong. You proposed marriage and courted me.

(Hawaii was annexed to the United States and became a Territory.)

This chapter was first published in Seaweeds and Constructions: Anthology Hawaii 6, 1979. 
- We had a child out of wedlock.

(The Hawaiian Homes Commission Act was created by Congress in 1920.)

- You fathered that child, and yet you did not provide support payment for that child.

(No money was given to fund the Hawaiian Homes

Commission Act.)

- And then to make our relationship legal, I badgered you, and so you married me.

(Hawaii became a State in 1959, a part of the United States.)

- By then you were taking full advantage of me, being entitled to my wifely possessions.

(You lost respect for my people. The Native Hawaiian people began to lose heavily, especially in the area of land possession.)

- You invited so many people into our home, entertaining them as you saw fit and you made up all the rules. I sat by submissively.

(People from all over the world reveled and played on the Hawaiian shores, coming to start their economic bases here-in the way of land investments, hotel building, etc. Slowly but surely our people were told to leave their ancestral grounds to make way for the newcomers.)

- We've been married close to 20 years now.

(Hawaii will celebrate its 20th year of Statehood in 1979.)

- Yet never in all these years have you given a penny to raise our child, who was born pre-maritally. He has suffered much, working his own way through life. He has given much of his life to please you.

(The Hawaiian Homes Commission Act was never funded and the government has used 44,000 acres out of approximately 200,000 acres. The federal government uses about 16,800 acres today. 30,000 acres are "missing.")

- You have beaten me repeatedly.

(My people have been evicted slowly but surely from their homelands and have become dispossessed.)

- I have become so scarred.

(Ugly buildings and highways mar my once beautiful landscape. Kahoolawe has been bombed mercilessly.)

- I feel haggard and ugly.

(My people are weary and are feeling very bitter.) 
- Fish that used to in the past, no longer come to play at my feet. (Even the food is far out of reach of my people. Fish prices are so high and there's a poi shortage because our ancestral farmlands on which we grew taro have been denied water, which has been diverted to sugarcane lands. So much of what we eat is imported.)

- I will no longer pity myself but must stand up to you. I will take this treatment no more.

(I will resist you in these demonstrations.)

- You had better straighten up, America, give restitution or ship out! (I give you a year to make reforms and show good faith. Do this or we will declare sovereignty — to be freed of your shackles.)

- I have options for the future. I could go to the police.

(I can ask the United Nations to step in-between us.)

- I could turn to the Women's Counseling Center.

(I could turn to my sisters in all of Polynesia.)

- And then, too, I could have an affair.

(Perhaps I can call Russia or the People's Republic of China to my defense. Or how about Cuba?)

- But then ... I really wouldn't want to do that. After all, I do have my pride. So for now, I will just settle to be introspective and think things over.

(I will turn to my Native Hawaiian people to direct a course of action.)

- But I did want to let you know of my thoughts for now and of possibilities for the future, before I act on my convictions. 